\title{
Influence of Amino Acids on the Synthesis of an Extracellular Proteinase from Staphylococcus aureus
}

\author{
By A. BJÖRKLIND AND S. ARVIDSON \\ Department of Bacteriology, Karolinska Institutet, S-104 01 Stockholm 60, Sweden
}

(Received 29 December 1977; revised 11 April 1978)

\begin{abstract}
The influence of amino acids on the synthesis of staphylococcal serine-proteinase (proteinase I) by Staphylococcus aureus strain v8 was studied. The repression of proteinase synthesis during the exponential growth phase was not due to any single amino acid in the medium. Proline was essential for proteinase synthesis in post-exponential growth but not for bacterial growth. At low concentrations of glycine, serine, threonine and proline, proteinase synthesis was inhibited, whereas at high concentrations of any of these amino acids, proteinase synthesis was fully induced. During post-exponential growth in the absence of glycine, serine, threonine or proline, the intracellular concentrations of alanine, aspartic acid and glutamic acid increased two to threefold. In the presence of these amino acids, the pool of alanine and aspartic acid remained at a low level and the concentration of glutamic acid decreased. The synthesis of proteinase $I$ is probably repressed at high intracellular concentrations of glutamic acid.
\end{abstract}

\section{INTRODUCTION}

At least three different extracellular proteolytic enzymes are produced by Staphylococcus aureus (Arvidson et al., 1972, 1973; Arvidson, $1973 a$; Björklind \& Jörnvall, 1974; Houmard \& Drapeau, 1972). One of these enzymes (proteinase I), which is a serine-proteinase (Dugas \& Gaudet, 1975), cleaves peptide bonds only at the carboxyl terminal side of glutamic acid and aspartic acid. Extracellular proteinases are thought generally to hydrolyse extracellular proteins to provide some of the amino acid requirement of the bacteria. This may not be the prime function of proteinase I, since peptides derived through hydrolysis of proteins by this enzyme are generally too large to be transported across the bacterial cell membrane (Payne \& Gilvarg, 1971) unless other proteinases are produced (proteinase II and III) (Arvidson, 1973 b; Björklind \& Jörnvall, 1974). In order to understand the physiological role of proteinase $\mathrm{I}$, we have investigated the regulation of the synthesis of this enzyme. The synthesis of extracellular proteinases is influenced by both amino acids and carbohydrates (Litchfield \& Prescott, 1970; Tanaka \& Iuchi, 1971; McDonald \& Chambers, 1966). Proteinase $I$ is produced mainly during the post-exponential growth phase in a complex amino acid medium with glycerol or glucose in excess; this suggests that its synthesis is not under catabolite repression (Arvidson et al., 1976). In the present study we have investigated the influence of amino acids on the synthesis of proteinase $I$.

\section{METHODS}

Bacterial strain. Staphylococcus aureus strain v8, which was used throughout this study, produces high levels of staphylococcal serine-proteinase (proteinase I) (Björklind \& Arvidson, 1977).

Cultivation media. Seed cultures were grown for $18 \mathrm{~h}$ in Trypticase Soy Broth (BBL) on a rotary shaker. Cultures were then grown in baffled shake flasks or in a 1 litre stirred fermenter (Biotec FL101, Stockholm, Sweden) using a casein hydrolysate medium (CC medium) (Arvidson et al., 1972) or a defined medium in 
Table 1. Final amino acid concentrations in the defined medium

\begin{tabular}{lclc}
\multicolumn{1}{c}{ Amino acid } & $\begin{array}{c}\text { Concn } \\
\left(\mathrm{mg} \mathrm{ml}^{-1}\right)\end{array}$ & \multicolumn{1}{c}{ Amino acid } & $\begin{array}{c}\text { Concn } \\
\left(\mathrm{mg} \mathrm{ml}^{-1}\right)\end{array}$ \\
L-Alanine & $\mathbf{0 . 7 0}$ & L-Lysine & 1.86 \\
L-Arginine & $\mathbf{0 . 7 8}$ & L-Methionine & 0.54 \\
L-Aspartic acid & 1.62 & L-Phenylalanine & 0.94 \\
L-Cysteine* & 0.25 & L-Proline & 1.64 \\
L-Glutamic acid $\dagger$ & 4.20 & L-Serine $\ddagger$ & 1.28 \\
Glycine & 0.40 & L-Threonine & 0.84 \\
L-Histidine & 0.58 & L-Tryptophan $\dagger$ & 0.40 \\
L-Isoleucine & 1.14 & L-Tyrosine§ & 1.46 \\
L-Leucine & 1.60 & L-Valine & 1.14
\end{tabular}

* Dissolved in $0.4 \mathrm{M}-\mathrm{NaOH}$; sterilized by filtration; prepared freshly each time.

$\dagger$ Dissolved in $0.4 \mathrm{M}-\mathrm{HCl}$; sterilized by filtration.

¥ Dissolved in distilled water; sterilized by filtration.

$\S$ Dissolved in $0.4 \mathrm{M}-\mathrm{NaOH}$; sterilized by filtration.

which the casein hydrolysate was replaced by $\mathrm{L}$-amino acids. All cultivation procedures have been described earlier (Arvidson et al., 1972). CC medium contained (per litre): casein hydrolysate (Oxoid), $40 \mathrm{~g}$; glycerol, $10 \mathrm{~g} ; \mathrm{Na}_{2} \mathrm{HPO}_{4} .2 \mathrm{H}_{2} \mathrm{O}, 1 \mathrm{~g} ; \mathrm{KH}_{2} \mathrm{PO}_{4}, 0.4 \mathrm{~g} ;\left(\mathrm{NH}_{4}\right)_{2} \mathrm{SO}_{4}, 1 \mathrm{~g}$; DL-tryptophan, $80 \mathrm{mg}$; L-cystine, $100 \mathrm{mg}$; thiamin, $2 \mathrm{mg}$; nicotinic acid, $4 \mathrm{mg}$; $\mathrm{MgSO}_{4} .7 \mathrm{H}_{2} \mathrm{O}, 170 \mathrm{mg}$; $\mathrm{MnSO}_{4} .4 \mathrm{H}_{2} \mathrm{O}, 10 \mathrm{mg}$; $\mathrm{FeSO}_{4} .7 \mathrm{H}_{2} \mathrm{O}, 6 \mathrm{mg}$; $\mathrm{CaCl}_{2} .2 \mathrm{H}_{2} \mathrm{O}, 147 \mathrm{mg}$; and citric acid, $6 \mathrm{mg}$. The amino acid content of the defined medium is given in Table 1. All amino acids were of Biopur quality (Merck). They were added as stock solutions (approximately 20 -fold concentrated) which were kept for not more than 2 weeks. The cysteine solution was prepared freshly each time. Serine, cysteine, tyrosine, glutamic acid and tryptophan were sterilized by filtration. When CC medium or defined medium was used for shake flask cultivation without $\mathrm{pH}$ control, glycerol was replaced by sodium $\beta$-glycerophosphate $\left(10 \mathrm{~g} \mathrm{l}^{-1}\right)$ plus sodium lactate $\left(5 \mathrm{~g}^{-1}\right)$ in order to maintain a neutral $\mathrm{pH}$. Dissolved oxygen tension in fermenter cultures was measured by an oxygen electrode (Borkowski \& Johnson, 1967).

Proteinase assay. Proteinase I activity in culture supernatant fluids was determined as described earlier, using casein as substrate (Arvidson, 1973b). Proteinase I (total amount of protein) was also determined by quantitative immunoelectrophoresis. The samples to be tested were run in an agarose gel containing monospecific proteinase I antiserum. The areas of the rockets were measured and compared with those of a standard preparation of highly purified proteinase I included on each gel (Laurell, 1966; Björklind \& Arvidson, 1977).

Extraction of the free intracellular amino acid pool. The intracellular amino acid pool was extracted from washed cells with boiling water for $15 \mathrm{~min}$ as described by Hancock (1958).

Amino acid determination. Thin-layer chromatography (Heathcote \& Haworth, 1969) was used for semiquantitative determination of amino acids in culture supernatant fluids and in the intracellular pool. The total amount of amino acids in the intracellular pool was determined by the ninhydrin reaction and expressed by reference to a glutamic acid standard. For more accurate quantification, some samples were analysed by a Durum amino acid analyser model D- 500 .

Metabolism of ${ }^{14} \mathrm{C}$-labelled amino acids by resting cell suspensions. Cells were grown for $4 \mathrm{~h}$ in $\mathrm{CC}$ medium containing only $10 \mathrm{mg}$ casein hydrolysate $\mathrm{ml}^{-1}$, washed once in $0.05 \mathrm{M}$-phosphate buffer $\mathrm{pH} 7.0$ at $4{ }^{\circ} \mathrm{C}$ and resuspended at a density of $1 \mathrm{mg}$ dry wt $\mathrm{ml}^{-1}$ in phosphate buffer $(0.05 \mathrm{M}, \mathrm{pH} 7.0)$ containing $1 \mathrm{mM}-\mathrm{Mg}^{2+}$ and $1 \mathrm{mM}-\mathrm{Ca}^{2+}$. At the start of the experiment, glycine, serine or threonine $\left(1 \mathrm{mg} \mathrm{ml}^{-1}\right)$ and the corresponding ${ }^{14} \mathrm{C}$-labelled amino acid $\left(0.4 \mu \mathrm{Ci} \mathrm{ml}^{-1}\right)$ were added. Each sample was incubated on a rotary shaker at $37^{\circ} \mathrm{C}$ for $90 \mathrm{~min}$. Portions $(5 \mathrm{ml}$ ) were withdrawn at $0,15,30$ and $90 \mathrm{~min}$, immediately chilled, and the cells were harvested by centrifugation. After resuspension in distilled water, the intracellular amino acid pool was extracted as described above. The extracted amino acids were analysed by thin-layer chromatography (Heathcote \& Haworth, 1969), and subsequent autoradiography using Agfa-Gevaert Osray M3-DW X-ray film. ${ }^{14} \mathrm{C}$-Labelled amino acids, purchased from New England Nuclear Chemicals, were chromatographically pure. 


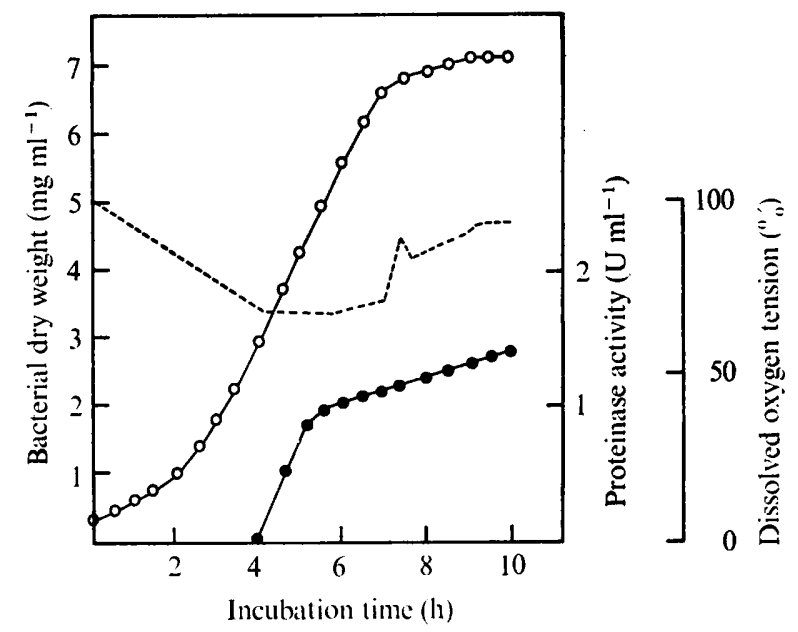

Fig. 1. Growth and proteinase I formation of $S$. aureus v8 in the defined amino acid medium. The experiment was performed in a stirred fermenter with pH control. $\bigcirc$, Bacterial dry weight $\left(\mathrm{mg} \mathrm{ml}^{-1}\right) ; 0$, proteinase I activity $\left(\mathrm{U} \mathrm{ml}^{-1}\right) ;---$, dissolved oxygen tension (\% saturation).

Table 2. Influence of the energy source in the medium on the consumption of amino acids and appearance of proteinase $I$

Staphylococcus aureus v8 was grown in a stirred fermenter in the defined medium with (i) glycerol, (ii) glycerophosphate plus lactate or (iii) no extra energy source. The amino acid consumption was analysed by thin-layer chromatography of culture supernatants withdrawn every $30 \mathrm{~min}$. The samples were also examined for proteinase I. The bacterial dry weights $\left(\mathrm{mg} \mathrm{ml}^{-1}\right)$ at which individual amino acids were exhausted from the medium are shown.

$\begin{array}{lccc}\text { Amino acid } & \text { Glycerol } & \begin{array}{c}\text { Glycero- } \\ \text { phosphate } \\ \text { and lactate }\end{array} & \begin{array}{c}\text { No extra } \\ \text { energy source }\end{array} \\ \text { Alanine } & \mathrm{NC} & \mathrm{NC} & 2 \cdot 8 \\ \text { Arginine } & 6 \cdot 9 & 5 \cdot 5 & 3.6 \\ \text { Glycine } & 4 \cdot 3 & 3 \cdot 4 & 2 \cdot 4 \\ \text { Serine } & 6 \cdot 3 & 5 \cdot 0 & 2 \cdot 8 \\ \text { Threonine } & 6.3 & 4 \cdot 5 & 1 \cdot 4 \\ \text { Start of proteinase I synthesis } & 2 \cdot 8-3.5 & 2 \cdot 5-3.0 & 2 \cdot 0-2 \cdot 5\end{array}$

NC, Not consumed.

\section{RESULTS}

\section{Production of proteinase in relation to amino acid consumption}

Bacterial growth and the production of proteinase $I$ in the defined medium is shown in Fig. 1. Bacterial growth proceeded at an exponential rate up to a dry weight of about $3 \cdot 2 \mathrm{mg}$ $\mathrm{ml}^{-1}$ after which the growth was linear for about one generation and then declined rapidly. Proteinase was produced mainly during the linear growth period and the rate of production dropped to low levels when the culture reached the stationary phase. The end of the exponential growth phase was not due to exhaustion of glycerol or oxygen limitation. In order to show that the repression of proteinase synthesis during the exponential growth phase was not due to the age of the seed culture, inocula were used that contained cells harvested at different times during growth. Proteinase I synthesis started at the end of the exponential growth phase irrespective of the origin of the inoculum. Analysis of culture supernatant fluids revealed that glycine, serine, threonine and arginine were exhausted from 
Table 3. Effect of omitting different amino acids from the defined medium on bacterial growth and proteinase I production

Proteinase I production was calculated per $\mathrm{mg}$ bacterial dry weight.

$\begin{array}{lcclcc}\text { Amino acid omitted } & \begin{array}{c}\text { Relative } \\ \text { bacterial } \\ \text { growth }\end{array} & \begin{array}{c}\text { Relative } \\ \text { proteinase I } \\ \text { production }\end{array} & \text { Amino acid omitted } & \begin{array}{r}\text { Relative } \\ \text { bacterial } \\ \text { growth }\end{array} & \begin{array}{c}\text { Relative } \\ \text { proteinase I } \\ \text { production }\end{array} \\ \text { None (control) } & 1.00 & 1.00 & & & \\ \text { Alanine } & 0.97 & 1.06 & \text { Cysteine } & 0.54 & 0.46 \\ \text { Aspartic acid } & 0.99 & 0.94 & \text { Histidine } & 0.46 & 0.46 \\ \text { Glutamic acid } & 1.05 & 1.02 & \text { Leucine } & 0.43 & 0.39 \\ \text { Glycine } & 0.89 & 0.98 & \text { Arginine } & 0.39 & 0.51 \\ \text { Tryptophan } & 0.89 & 0.18 & \text { Phenylalanine } & 0.37 & 0.83 \\ \text { Lysine } & 0.86 & 0.87 & \text { Tyrosine } & 0.37 & 0.38 \\ \text { Serine } & 0.74 & 0.45 & \text { Methionine } & 0.32 & 0.60 \\ \text { Proline } & 0.74 & 0.00 & \text { Valine } & 0.29 & 0.00 \\ \text { Isoleucine } & 0.73 & 0.73 & \text { Threonine } & 0.24 & 0.21\end{array}$

the medium during the period of linear growth, but the time of exhaustion was not correlated with the appearance of proteinase I (Table 2 ). When glycerol was omitted from the medium the growth was exponential up to a dry weight of 2 to $2.5 \mathrm{mg} \mathrm{ml}^{-1}$ and the growth rate was much lower than in the presence of glycerol. The final growth yield was also lower and, as expected, the rate of amino acid consumption was higher. Proteinase synthesis started at the end of the exponential phase at a dry weight of 2 to $2.5 \mathrm{mg} \mathrm{m}^{-1}$. With glycerophosphate plus lactate as energy source, the results were essentially the same as with glycerol, both in the stirred fermenter and in shake flasks.

\section{Influence of individual amino acids on proteinase production}

To find out if the repression of proteinase I synthesis during the exponential growth phase was due to the presence of any particular amino acid, individual amino acids were omitted from the medium. All experiments were carried out in shake flask cultures, using glycerophosphate plus lactate as energy source. One control culture was included with each set of experimental cultures in order to eliminate minor differences between different batches of amino acid stock solutions. The results of omitting individual amino acids from the medium are given in Table 3. Proteinase I synthesis never started before the end of the exponential growth phase. However, omission of individual amino acids affected the amounts of proteinase synthesized.

The omission of alanine, aspartic acid, glutamic acid, glycine or lysine had little effect on growth or proteinase synthesis. In the absence of proline, serine or tryptophan, proteinase synthesis was greatly reduced, but again bacterial growth was little affected. In the absence of tryptophan, the growth rate was reduced, while the final cell yield was almost the same as in the control. Omission of proline from the medium resulted in complete absence of proteinase synthesis. The omission of all other amino acids resulted in very poor bacterial growth and usually very little proteinase was produced. In the absence of threonine there was little growth. Since in the defined medium without glycerophosphate plus lactate, threonine was exhausted very early during growth (Table 2) without any significant effect on growth or proteinase I production, it is possible that threonine is essential for the initiation of bacterial growth. In a medium with only $0.04 \mathrm{mg}$ threonine $\mathrm{ml}^{-1}$, bacterial growth was almost the same as in the complete medium containing $0.84 \mathrm{mg} \mathrm{ml}^{-1}$, but no proteinase I was produced. Glutamine and asparagine were not included in the original defined medium. However, the addition of these amino acids each at a concentration of $4.0 \mathrm{mg}$ $\mathrm{ml}^{-1}$ did not affect bacterial growth or proteinase I production. 


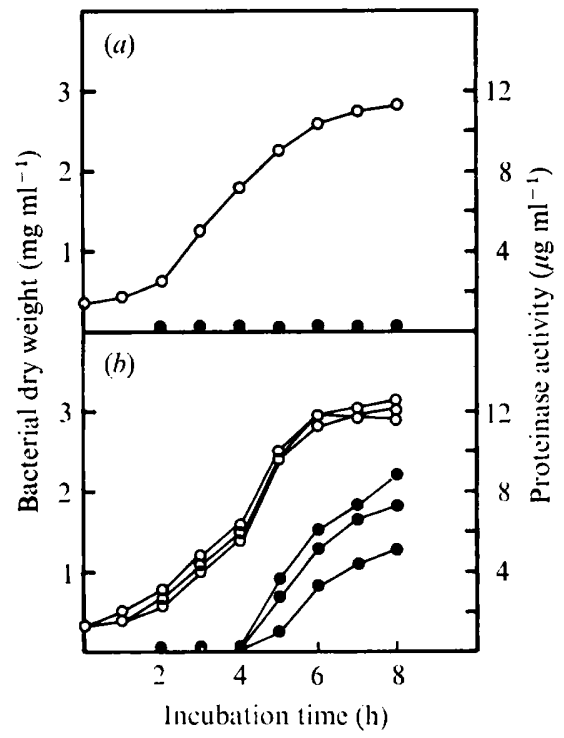

Fig. 2

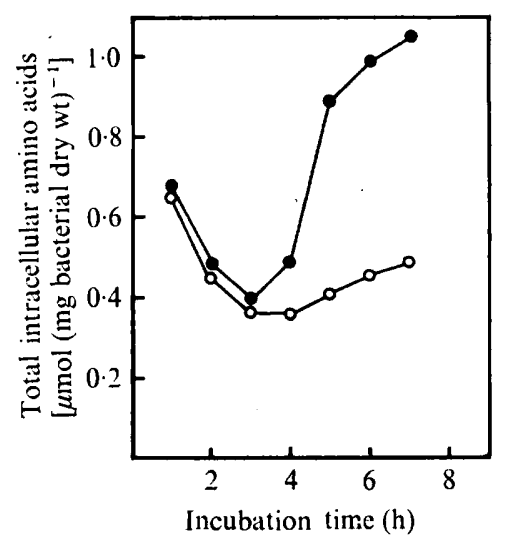

Fig. 3

Fig. 2. Effect of glycine, serine or threonine on proteinase I synthesis. Staphylococcus aureus v8 was grown in shake flasks in CC medium containing $10 \mathrm{mg}$ casein hydrolysate $\mathrm{ml}^{-1}(a)$ or in the same medium plus $1 \mathrm{mg}$ glycine, serine or threonine $\mathrm{ml}^{-1}(b)$. $\bigcirc$, Bacterial dry weight $\left(\mathrm{mg} \mathrm{ml}^{-1}\right)$; $\odot$, proteinase $\mathrm{I}$ activity $\left(\mu \mathrm{g} \mathrm{ml}^{-1}\right)$.

Fig. 3. Effect of serine on the total intracellular amino acid pool. Staphylococcus aureus v8 was grown in CC medium containing $10 \mathrm{mg}$ casein hydrolysate $\mathrm{ml}^{-1}(0)$ or in the same medium plus $1 \mathrm{mg}$ serine $\mathrm{ml}^{-1}(\mathrm{O})$. The intracellular amino acid pool was extracted from cells harvested at intervals and analysed by the ninhydrin reaction.

\section{Stimulation of proteinase production by glycine, serine or threonine}

Analysis of amino acid consumption during all growth phases revealed that most amino acids except glycine, serine and threonine (see above) were in excess, both in the defined medium and in CC medium. When the concentration of casein hydrolysate in CC medium was reduced to $10 \mathrm{mg} \mathrm{ml}^{-1}$, no proteinase I was produced. The rate and duration of the exponential growth were almost unchanged, while the rate of the post-exponential growth was markedly reduced. These results indicate that the cessation of exponential growth in cultures grown in the complete $\mathrm{CC}$ medium is not due to amino acid limitation, and the production of proteinase I during post-exponential growth is dependent on the presence of some particular amino acids. The effects of adding individual amino acids to the 'low amino acid medium' at final concentrations of $1 \mathrm{mg} \mathrm{ml}^{-1}$ was studied. When glycine, serine or threonine was added to the medium the rate of post-exponential growth was increased to about the same level as seen with the complete CC medium and large amounts of proteinase I were produced (Fig. 2). The production of proteinase III, alfa-toxin and acid phosphatase was stimulated under the same conditions; the synthesis of staphylokinase, however, was not stimulated by glycine, serine or threonine. The addition of proline or tryptophan, which were essential for proteinase synthesis (see above), had no effect in these experiments, indicating that these amino acids were in excess. When glycine, serine or threonine was added to growing cultures just after the exponential growth period had ended, proteinase I synthesis started almost immediately. Three times more proteinase was produced than in cultures where the amino acids were added at the start of the cultivation, indicating that the yield of proteinase is dependent on the concentration of glycine, serine or threonine in the medium at the start of proteinase I synthesis. This was confirmed by adding different concentrations of the amino acids to the medium. 
Table 4. Amino acid concentrations in exponentially growing $S$. aureus v8

The bacteria were grown in CC medium containing $10 \mathrm{mg}$ casein hydrolysate $\mathrm{ml}^{-1}$ and no extra amino acids. Intracellular amino acids were extracted and analysed as described in Methods. Concentrations are expressed as nmol (mg bacterial dry wt) ${ }^{-1}$.

$\begin{array}{lrlc}\text { Amino acid } & \text { Concn } & \text { Amino acid } & \text { Concn } \\ \text { Glutamic acid } & 131 \cdot 0 & \text { Valine } & 5 \cdot 4 \\ \text { Alanine } & 127.9 & \text { Isoleucine } & 4 \cdot 1 \\ \text { Proline } & 61.8 & \text { Cysteine } & 3.5 \\ \text { Aspartic acid } & 29.7 & \text { Phenylalanine } & 2 \cdot 1 \\ \text { Lysine } & 12.9 & \text { Methionine } & 1.4 \\ \text { Serine } & 8 \cdot 2 & \text { Glycine } & 1 \cdot 2 \\ \text { Tyrosine } & 6.4 & \text { Threonine } & 1 \cdot 1 \\ \text { Leucine } & 5.9 & & \end{array}$
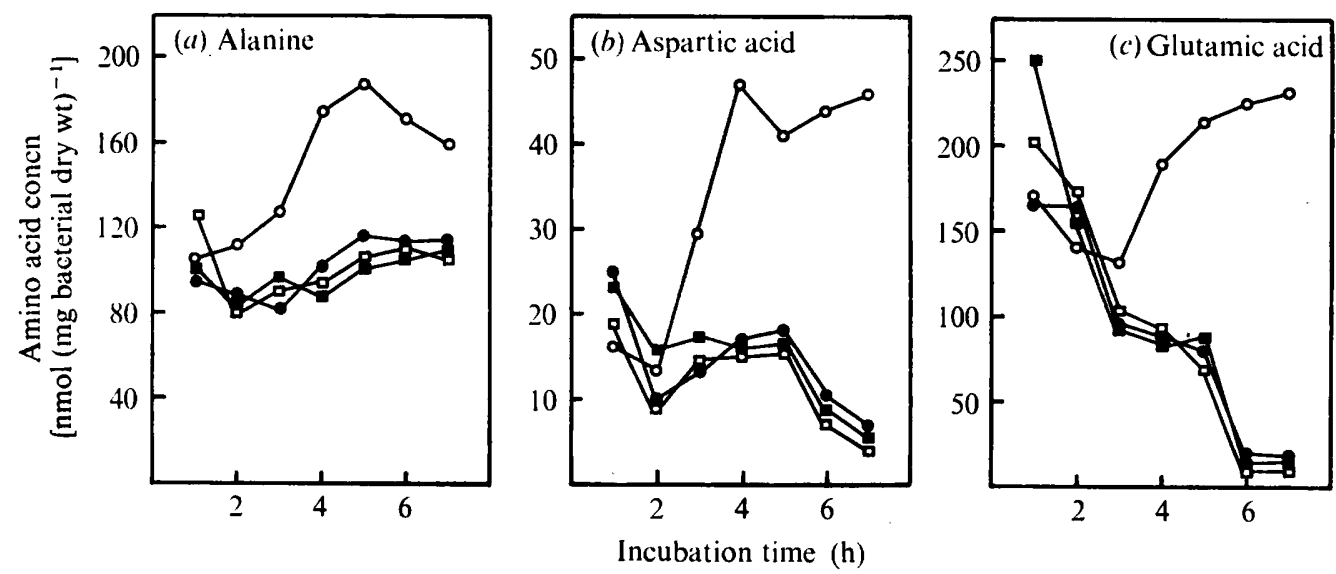

Fig. 4. Intracellular concentrations of $(a)$ alanine, $(b)$ aspartic acid and (c) glutamic acid. Staphylococcus aureus $\mathrm{v} 8$ was grown in CC medium containing $10 \mathrm{mg}$ casein hydrolysate $\mathrm{ml}^{-1}$ plus $1 \mathrm{mg}$ glycine $\mathrm{ml}^{-1}(0)$ or $1 \mathrm{mg}$ serine $\mathrm{ml}^{-1}(\square)$ or $1 \mathrm{mg}$ threonine $\mathrm{ml}^{-1}(\square)$ or without extra amino acid (○).

\section{Proteinase synthesis in relation to the concentration of intracellular amino acids}

The total intracellular amino acid concentration was analysed in cells harvested at different times during growth. In cells grown in CC medium with $10 \mathrm{mg}$ casein hydrolysate $\mathrm{ml}^{-1}$, the concentration of intracellular amino acids decreased from 0.6 to $0.3 \mu \mathrm{mol}$ (mg dry wt) ${ }^{-1}$ during exponential growth, but then increased to about $1 \mu \mathrm{mol}$ (mg dry wt) ${ }^{-1}$ by the end of post-exponential growth (Fig. 3). In cultures with additional glycine, serine or threonine, the intracellular amino acid concentration remained low during post-exponential growth. Amino acid analysis revealed that alanine, glutamic acid, aspartic acid and proline were the predominant intracellular amino acids during exponential growth. Table 4 shows the concentrations at the transition between exponential and post-exponential growth. The low level of the intracellular amino acid pool during post-exponential growth in the presence of glycine, serine or threonine was mainly due to decreased concentrations of alanine, glutamic acid and aspartic acid (Fig. 4). When glycine, serine or threonine was added during post-exponential growth, when the intracellular amino acid concentration was high, proteinase synthesis was induced and the intracellular amino acid concentration started to decrease (Fig. 5).

Analysis of cells grown in the complete defined medium revealed that the intracellular amino acid concentration was about $0.5 \mu \mathrm{mol}$ (mg dry wt) ${ }^{-1}$ during the period of proteinase I synthesis. The composition of the pool was the same as in cells grown in $\mathrm{CC}$ medium. In 

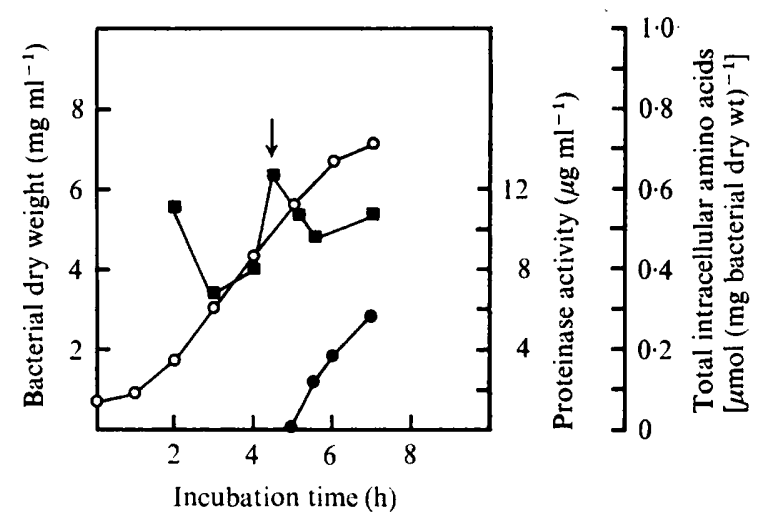

Fig. 5. Effect of adding serine to a growing culture of $S$. aureus v8. Cultural conditions were the same as in Fig. 2 except that serine was added during post-exponential growth as indicated by the arrow. $\bigcirc$, Bacterial dry weight $\left(\mathrm{mg} \mathrm{ml}^{-1}\right) ; 0$, proteinase I activity $\left(\mu \mathrm{g} \mathrm{ml}^{-1}\right) ; \mathbf{\square}$, intracellular amino acid concentration [ $\left.\mu \mathrm{mol}(\mathrm{mg} \text { bacterial dry } \mathrm{wt})^{-1}\right]$.

cells grown in the absence of proline, where no proteinase I was synthesized, the intracellular amino acid concentration increased to about $1 \mu \mathrm{mol}(\mathrm{mg} \text { dry wt })^{-1}$ during post-exponential growth, mainly due to accumulation of glutamic acid, aspartic acid and alanine, as revealed by thin-layer chromatography.

\section{Metabolism of ${ }^{14}$ C-labelled glycine, serine and threonine}

Since glycine, serine and threonine are closely related, and each can stimulate proteinase I synthesis, their metabolic fates were examined. Experiments with ${ }^{14} \mathrm{C}$-labelled glycine, serine or threonine revealed that threonine was rapidly converted to glycine and later to serine. In addition threonine was converted to glutamic acid and several unidentified compounds. Glycine, however, was almost exclusively converted to serine, and no threonine was found even after $90 \mathrm{~min}$ incubation. With serine, trace amounts of glycine were found, but no threonine. However, serine was rapidly converted to aspartic acid, alanine and three unidentified compounds.

\section{DISCUSSION}

The synthesis of staphylococcal serine-proteinase (proteinase 1) seemed to be totally repressed during exponential growth and was derepressed during post-exponential growth only when glycine, serine or threonine was present in the culture medium. (The terms 'repressed' and 'derepressed' refer simply to levels of estimated proteinase I; genetic control is implied rather than proven.) The appearance of proteinase $I$ in the culture at the end of the exponential growth phase could not be correlated exactly with the exhaustion of any particular nutrient or of oxygen in the medium. At present the reason for the decline in growth rate in the presence of excess nutrients is obscure. Holme \& Arvidson (1976) have previously shown that the molar growth yield for oxygen starts to decrease at the end of the exponential growth phase, due possibly to an uncoupling of oxidative phosphorylation or to an increase in the maintenance energy requirement. It is possible that the cessation of exponential growth is due to the accumulation of a metabolite which inhibits the energy metabolism (Landwall \& Holme, 1977).

The syntheses of several extracellular enzymes seem to be repressed during exponential growth (Pollock, 1962). Various mechanisms have been proposed, which all fit the hypothesis that the function of most extracellular hydrolytic enzymes is to provide the cells with lowmolecular weight nutrients under conditions of nutrient limitation or starvation. Coleman (1967) and Coleman \& Stormonth (1973) showed that amylase and proteinase synthesis in 
Bacillus amyloliquefaciens and Bacillus subtilis were repressed during exponential growth. They suggested that exoprotein synthesis was regulated by the intracellular nucleotide pool, which increased during post-exponential growth. Later, Abbas-Ali \& Coleman (1977) were able to demonstrate the same phenomenon in $S$. aureus strain Wood 46 , studying the synthesis of alfa-toxin and total extracellular proteins. We have not been able to repeat this in $S$. aureus strain v8 using the Coleman \& Stormonth (1973) methods. So far we have no explanation for this difference. One type of repression, similar to catabolite repression, was demonstrated for extracellular proteinase in Vibrio parahaemolyticus by Tanaka \& Iuchi (1971). Proteinase synthesis was repressed by glucose and other easily usable energy sources, but cyclic AMP did not overcome this repression. The results obtained by McDonald \& Chambers (1966), who studied proteinase production in a strain of Micrococcus freundenreichii, could also be interpreted as catabolite repression. They stated that proteinase synthesis was stimulated under conditions of energy starvation, suggesting that the function of the proteinase was to ensure a supply of carbon rather than amino acids for protein synthesis. For proteinase I, synthesis may be controlled by catabolite repression not directly effected by carbohydrates, since proteinase I synthesis could be induced in the presence of glycerol or glucose (Arvidson et al., 1976).

One of the most interesting findings was that proteinase I was synthesized during postexponential growth only in the presence of glycine, serine or threonine. The experiments with ${ }^{14} \mathrm{C}$-labelled amino acids suggest that serine was the effector of proteinase stimulation. It is not very likely that serine is essential as such for the synthesis of proteinase I, but acts indirectly by changing the intracellular amino acid pool. Proline, which was also found to be essential for proteinase synthesis, seems to act in the same way by affecting the intracellular concentrations of glutamic acid, aspartic acid and alanine. These three amino acids can act as amino group donors in transamination reactions. It is suggested that they are accumulated in order to meet the demand for amino groups needed for the synthesis of serine, glycine, threonine and proline.

Proteinase III, acid phosphatase and alfa-toxin were also repressed under the same conditions as proteinase $I$. We thus propose that there is a preferential synthesis of cellular proteins under the conditions of amino acid limitation, the formation of extracellular protein being repressed by high intracellular concentrations of glutamic acid, aspartic acid and alanine.

As already stated, the synthesis of proteinase I was repressed during exponential growth in CC medium supplemented with extra glycine, serine or threonine. Since the intracellular concentrations of alanine and aspartic acid were about the same during exponential and post-exponential growth in these cultures (Fig. 4), the repression of proteinase I synthesis during the exponential growth period could not be due to these amino acids. However, the intracellular concentration of glutamic acid decreased during post-exponential growth in the presence of glycine, serine or threonine. It is suggested that the synthesis of proteinase I and possibly other extracellular proteins is repressed by high concentrations of glutamic acid. It is, however, also possible that different mechanisms are operating during exponential and post-exponential growth.

This work was supported by the Swedish Medical Research Council (project no. 4513). The skilful technical assistance of Mrs I. Möllegård, U. Björk and M. Tigerholm is gratefully acknowledged. Our sincere thanks are also due to Dr Bertil Genfors at Vitrum AB, Stockholm, for performing quantitative amino acid analyses. 


\section{REFERENCES}

AbBas-Ali, B. \& Coleman, G. (1977). The characteristics of extracellular protein secretion by Staphylococcus aureus (Wood 46) and their relationship to the regulation of alpha-toxin. Journal of General Microbiology 99, 277-282.

Arvinson, S. (1973a). Studies on extracellular proteolytic enzymes from Staphylococcus aureus. II. Isolation and characterization of an EDTAsensitive protease. Biochimica et biophysica acta 302, 149-157.

ARvidson, S. (1973b). Hydrolysis of casein by three extracellular proteolytic enzymes from Staphylococcus aureus, strain v8. Acta pathologica et microbiologica scandinavica B81, 538-544.

Arvidson, S., Holme, T. \& Lindholm, B. (1972). The formation of extracellular proteolytic enzymes from Staphylococcus aureus. Acta pathologica et microbiologica scandinavica B80, 835-844.

Arvidson, S., Holme, T. \& Lindholm, B. (1973). Studies on extracellular proteolytic enzymes from Staphylococcus aureus. I. Purification and characterization of one neutral and one alkaline protease. Biochimica et biophysica acta 302, 135148.

ARvidson, S., BJörklind, A., ERIKSSON, R. \& Holme, T. (1976). Enzymes from Staphylococcus aureus. In Continuous Culture: Applications and New Fields, Proceedings of the 6th International Symposium on Continuous Culture of Microorganisms, pp. 238-250. Edited by A. C. R. Dean, D. C. Ellwood, C. G. T. Evans \& J. Melling. Chichester: Ellis Horwood.

BJörklind, A. \& ARvidson, S. (1977). Occurrence of an extracellular serine-proteinase among staphylococcal strains. Acta pathologica et microbiologica scandinavica B85, 277-280.

Björklind, A. \& Jörnvall, H. (1974). Substrate specificity of three different extracellular proteolytic enzymes from Staphylococcus aureus. Biochimica et biophysica acta 370, 524-529.

Borkowski, J. D. \& JoHnson, M. J. (1967). Longlived steam-sterilizable membrane probes for dissolved oxygen measurements. Biotechnology and Bioengineering 9, 635-639.

Coleman, G. (1967). Studies on the regulation of extracellular enzyme formation by Bacillus subtilis. Journal of General Microbiology 49, 421-431.

Coleman, G. \& Stormonth, D. A. (1973). The relationship between the nucleotide pool of Bacillus amyloliquefaciens and the control and secretion of extracellular enzymes. Biochemical Society Transactions 1, 394-397.

Dugas, H. \& GaudeT, F. (1975). Structural studies of staphylococcal protease. I. Spin labelling of the active site and a comparison with other proteases. Canadian Journal of Biochemistry 53, 155-163.

HANCOCK, R. (1958). The intracellular amino acids of Staphylococcus aureus: release and analysis. Biochimica et biophysica acta 28, 402-412.

Heathicote, J. G. \& Haworth, C. (1969). An improved technique for the analysis of amino acids and related compounds on thin layers of cellulose. II. The quantitative determination of amino acids in protein hydrolysates. Journal of Chromatography 43, 84-92.

Holme, T. \& ARvidson, S. (1976). Changes in $\mathrm{Y}_{\mathrm{O}_{2}}$ in relation to growth rate and production of extracellular enzymes by Staphylococcus aureus. Zentralblatt für Bakteriologie, Parasitenkunde, Infektionskrankheiten und Hygiene (Abteilung I) Suppl. 5. 181-188.

Houmard, J. \& Drapeau, G. R. (1972). Staphylococcal protease: a proteolytic enzyme specific for glutamoyl bonds. Proceedings of the National Academy of Sciences of the United States of America 69, 3506-3509.

LANDWALL, P. \& Holme, T. (1977). The removal of inhibitors of bacterial growth by dialysis culture. Journal of General Microbiology 103, 345-352.

LAURELL, C. B. (1966). Quantitative estimation of proteins by electrophoresis in agarose gel containing antibodies. Analytical Biochemistry 15, 45-52.

Litchfield, C. D. \& Prescott, J. M. (1970). Regulation of proteolytic enzyme production by Aeromonas proteolytica. I. Extracellular endopeptidase. Canadian Journal of Microbiology 16, 17-22.

McDonald, I. J. \& Chambers, A. K. (1966). Regulation of proteinase formation in a species of Micrococcus. Canadian Journal of Microbiology 12, 1175-1185.

Payne, J. W. \& Gilvarg, C. (1971). Peptide transport. Advances in Enzymology 35, 187-244.

Pollock, M. R. (1962). Exoenzymes. In The Bacteria, vol. 4, pp. 121-178. Edited by I. C. Gunsalus \& R. Y. Stanier. New York and London: Academic Press.

TANAKA, S. \& IUCHI, S. (1971). Induction and repression of an extracellular proteinase in Vibrio parahemolyticus. Biken Journal 14, 81-96. 